\title{
References:
}

1. Иванов А. В. Портфолио в начальной школе: пособие для учителя общеобразоват. учрежд. / А. В. Иванов. Москва, 2012. 198 с.

2. Ткаченко Л. П. Реалізація інноваційних педагогічних технологій у процесі вивчення курсу риторики. Педагогіка та психологія: збірник наукових праць/ Л. П. Ткаченко. Вип. 53. Харків, 2016. С. 92-102.

3. Фіцула М. М. Педагогіка вищої школи / Академвидав. Київ, 2006. $352 \mathrm{c}$.

DOI https://doi.org/10.30525/978-9934-588-90-7-85

\section{ВИКОРИСТАННЯ КЕЙС МЕТОДУ У ФОРМУВАННІ ІНШОМОВНОЇ КОМУНІКАТИВНОЇ КОМПЕТЕНЦІЇ СТУДЕНТІВ МЕДИЧНИХ ЗВО}

\author{
Максимова О. П. \\ кандидат педагогічних наук, \\ дочент кафедри мовних та гуманітарних дисииплін № 2 \\ Донеиький національний медичний університет \\ Шульга Н. В. \\ викладач кафедри мовних та гуманітарних дисциилін № 2 \\ Донеиький національний медичний університет \\ м. Кропивницький, Украӥна
}

Інтеграція освіти України у світовий освітній простір відповідно до Болонського процесу, безперервний та інтенсивний розвиток медичної науки висувають нові цілі і завдання при підготовці фахівців-медиків, які знаходять відображення в державних стандартах вищої професійної освіти України [1]. Ці цілі і завдання стосуються не лише профільних і спеціальних медичних дисциплін, але й дисциплін базового загальноосвітнього циклу, зокрема навчання іноземній мові та іноземній мові за професійним спрямуванням.

Навчання іноземній мові за професійним спрямуванням грунтується на урахуванні потреб студентів у вивченні іноземної мови, зумовлених характерними особливостями професії або спеціальності, які, в свою чергу, вимагають іï вивчення [2]. В цьому полягає основна відмінність навчання іноземній мові за професійним спрямуванням від навчання мові для загальноосвітніх цілей i соціалізації. Метою професійно 
орієнтованого навчання іноземній мові у медичних ЗВО виступає оволодіння майбутніми медиками основами комунікативної компетенції.

Аналіз праць, присвячених формуванню комунікативної компетенції (Л.Б. Алексєєва, І.Л. Бім, О.О. Леонтьєв, С.Л. Рубінштейн, С. Муаран, Д. Хаймз та ін.), дозволяє зробити висновок, що комунікативну компетенцію слід розуміти як знання не лише мовних форм (засвоєння граматики і лексики), але також і набуття навичок їх використання для цілей реальної комунікації.

Формування і розвиток комунікативної компетенції майбутніх лікарів в процесі вивчення іноземної мови за професійним спрямуванням здійснюється з урахуванням реальних комунікативних потреб майбутніх фахівців в усіх сферах професійного спілкування. Мета комунікативної компетенції: уміти складати монологічне висловлювання на медичну тему; професійно спілкуватися з колегами і пацієнтами 3 дотриманням норм мовного етикету; брати участь у бесіді; аргументовано висловлювати власну позицію і адекватно сприймати мову співрозмовника; формулювати питання і обгрунтовано відповідати на них; володіти мовною ситуацією в професійній сфері спілкування.

Комунікативна спрямованість найбільш продуктивно реалізується за допомогою активних методів навчання, групових форм взаємодії суб'єктів навчання на заняттях, а також засобами інноваційних технологій. Для навчання професійній іноземній мові необхідно опанувати такі методи, як кейс метод, проектний метод, ділова гра, створення проблемної ситуації. Застосовуючи такі методи викладач методах перетворюється на консультанта, порадника, а не на звичайного лектора. Вже недостатньо навчати просто умінню читати i перекладати, пояснювати граматичні правила. Важливо, щоб той, кого навчають, міг висловити свою думку, посперечатися, обговорити, зробити висновок, підтримати бесіду іноземною мовою у сфері своєї майбутньої професійної діяльності.

Якщо говорити про вживання кейс методу на заняттях з іноземної мови, то даний метод допомагає максимально наблизити ситуації спілкування на заняттях до реальних життєвих ситуацій, 3 якими студенти стикатимуться в повсякденному житті і професійній діяльності. Кейс (від англ. саse - скринька, футляр, сумка) означає «всебічне активне вивчення матеріалу, як під керівництвом викладача, так і в групі, з метою отримання якомога більше відомостей з проблеми, що вивчається, для аналізу і прийняття оптимального рішення практичної ситуації» [3]. Знайомство 3 кейсом, самостійний пошук рішення (внутрішне монологічне мовлення іноземною мовою), процес аналізу ситуації під 
час заняття (монологічне i діалогічне мовлення, підготовлене i спонтанне, також іноземною мовою) - все це приклади комунікативних завдань. Аудиторне спілкування, пов'язане з роботою над кейсом, якому властиві суперечка, дискусія, аргументація, опис, порівняння, переконання і інші мовні акти, тренує навик вироблення правильної стратегї мовної поведінки, дотримання норм i правил іншомовного спілкування. Коментарі студентів за змістом кейса оцінюються викладачем за наступними навиками: аналітичний, управлінський, навик ухвалення рішення, навик міжособового спілкування, творчий підхід, навик усного і письмового спілкування іноземною мовою (лексикограматичний аспект). Виходячи 3 цього, кейс метод включає одночасно i особливу форму учбового матеріалу, і особливі способи його використання в практиці іноземної мови [4, с. 28]. Іншомовна комунікативна діяльність здійснюється в наступній послідовності: обговорення отриманої інформації, що міститься в кейсі; виділення найбільш важливої інформації; обмін думками і складання плану роботи над проблемою; робота над проблемою (дискусія); вироблення вирішення проблеми; дискусія для ухвалення остаточного рішення; підготовка доповіді; аргументована доповідь.

Таким чином, використання кейс методу передбачає досягнення певних результатів, а саме: збільшення об'єму професійної лексики; підвищення мотивації до вивчення іноземної мови; усвідомлення значущості уміння спілкуватися іноземною мовою; формування міжкультурної мовної компетенції.

\section{Література:}

1. Модернізація вищої освіти України i Болонський процес: Матеріали до першої лекції / Уклад. М.Ф. Степко, Я.Я. Болюбаш, К.М. Левківський, Ю.В. Сухарніков; відп. ред. М.Ф. Степко. - К. : Освіта України, 2004. 24 с.

2. Берман И.М. Методика обучения английскому языку в неязыковых вузах. М. : Высшая школа, 1970. 232 с.

3. Гончаренко С. Український педагогічний словник. К. : Либідь, 1997. 376 c.

4. Гейхман Л.К. Дистанционное образование в свете интерактивного подхода / Матер. II Международ. науч.-практ. конф. (Пермь, 6-8 февраля 2007 г.). Пермь: Изд-во ПГТУ, 2006. С. 25-32. 